\title{
Persistent Organic Pollutants (POPs)
}

\section{How to Deal with Persistent Organic Pollutants (POPs)?}

\author{
Editors: Walter Klöpffer ${ }^{1}$ and Martin Scheringer ${ }^{2}$ \\ ${ }^{1}$ Prof. Dr. Walter Klöpffer, Assessment of Chemicals, Products and Systems, CAU GmbH, Daimlerstr. 23, D-63303 Dreieich; \\ e-mail: w.kloepffer@cau-online.de \\ ${ }^{2}$ Dr. Martin Scheringer, Safety and Environmental Technology Group, Laboratory of Chemical Engineering, \\ Swiss Federal Institute of Technology, ETH Hönggerberg, CH-8093 Zürich, Switzerland; e-mail: scheringer@tech.chem.ethz.ch
}

The international negotiations (see Johannesburg, South Africa, December 2000 and Stockholm, Sweden, May 2001) about an 'International, Legally Binding Instrument for Implementing International Action on Certain Persistent Organic Pollutants' stimulated new interest in the environmental behavior of POPs and semivolatile chemicals in general, and also in the assessment procedures for such chemicals (reaching from scientific criteria to legal instruments). For these reasons, a series of articles with three main topics started in UWSF - Z. Umweltchem. Ökotox. and ESPR - Environ. Sci. \& Pollut. Res.: (i) the international negotiations (Ed. K.-G. Steinhäuser), (ii) the application of the precautionary principle and socio-economic questions connected with the POPs convention (Ed. H. Hulpke), and (iii) scientific questions about the environmental behavior of POPs (Ed. M. Scheringer). The series began with an opening paper by W. Klöpffer and M. Scheringer in UWSF - Z. Umweltchem. Ökotox. 12 (6) 307-309 (2000), continued with four articles in UWSF No. 1-4 published to date in 2001 , and will proceed with various contributions to the three topics appearing throughout the next two or three years either in UWSF (in German) or in ESPR (in English). An extended summary of each article will be published in the other respective journal. The summary of the opening paper was published in ESPR No. 1, 2001 (p. 63). Summaries of subsequent articles can be seen here.

\section{Summaries}

\section{Global Treaty for the Regulation of POPs: The Stockholm Convention}

(Globaler Vertrag zur Regelung von POPs: Die Stockholm Konvention)

[UWSF - Z Umweltchem Ökotox 13 (1) 39-44 (2001)]

\author{
Steffi Richter ${ }^{1}$, Klaus-G. Steinhäuser ${ }^{1}$ and Heidelore Fiedler ${ }^{2}$ \\ 1 Federal Agency for the Environment (Umweltbundesamt), POB 3300 22, D-14191 Berlin, Germany \\ ${ }_{2}$ UNEP Chemicals, 11-13, Chemin des Anémones, CH-1219 Châtelaine (GE), Switzerland
}

Corresponding author: Dr. Steffi Richter; e-mail: steffi.richter@uba.de

The success of the negotiations on the POPs Convention after the failure of the negotiations over the climate protocol in The Hague - in late November (Johannesburg, South Africa, 4 to 10 November 2000) is an important result for international action to protect the earth from damage by chemicals. It shows the countries' real commitment to find compromises for protection of the environment and human health and for the restoration of damaged ecosystems on our planet. It deserves to be highlighted that all participants - not only the industrialized countries but also developing countries as well as environmental organizations and the (chemical) industry - regard the conclusion of this convention as a success and that a broad basis for joint action has thus been created. The convention is a signal also because of its useful contents, which includes instruments for the total elimination of 12 POPs in the beginning and of further persistent organic pollutants at a later stage. The basis for a gradual reduction of the increasing pollution of the environment on a global scale is given by mechanisms for subjecting further POPs to the requirements of this Convention in the future. 